\title{
LIMITATION OF HIP JOINT MOVEMENT AS A FACTOR IN TRAUMATIC OSTEITIS PUBIS
}

\author{
J. G. P. WILLIAMS, M.Sc., F.R.C.S. Ed., D.Phys.Med. \\ Farnham Park Rehabilitation Centre, Slough, Buckinghamshire
}

\section{INTRODUCTION}

Traumatic osteitis pubis is well-documented and numerous references are to be found in the literature, where it is known by a variety of different names Tenosteochondrosis of the Pubis (Rosenklint and Bach Anderson 1969), Gracilis Syndrome (Schneider 1963), Dynamic Osteopathy of the Pubis (Losada and Saldias 1968), Pelvic adductor syndrome (Reideberger, Luschnitze and Bauchspeiss 1967) and Inguinocrural pain of footballers (Carnevale 1954).

\section{CLINICAL FEATURES}

Essentially, patients complain of pain in the groins, particularly when exercising energetically, and this pain may persist at rest in severe cases. At times, the clinical picture may mimic adductor origin strain but the diagnosis is clearly established on examination when the patient is found to be more-or-less acutely tender over the symphysis pubis. Unlike the case in rider's strain, pain is not always elicited by forced abduction of the thighs. Pain is, however, felt on certain hip movements and this pain may be felt in the hip or in the region of the symphysis (Williams 1976). The nature of the condition has been in dispute. Various possible pathologies have been postulated including infection and avascular necrosis. The usual histological findings are consistent with infarction of the symphysis. Lettin, in a communication to the Innominate Society has postulated that the condition is brought about by subchondral trabecular fractures akin to stress fracture.

X-ray appearances in well-established cases are quite typical with erosion and disordered calcification at the symphysis (Harris and Murray 1974), (Figure 1).

\section{AETIOLOGY}

Despite the interest recorded in this condition, no single primary cause has been elicited. The cases presently described suggest a mechanical factor in the development of the condition, an understanding of which may assist in long-term management.

\section{CLINICAL MATERIAL}

Twelve cases of clincal traumatic osteitis pubis have been seen in the Regional Sports Injuries Centre at
Farnham Park Rehabilitation Centre during the period July 1975 to August 1977, details of which are presented in Table I.

All patients showed some loss of hip mobility, invariably internal rotation (normal ranges $40^{\circ}$ in extension, $45^{\circ}$ in flexion (Russe and Gerhardt 1975) and in some cases external rotation, a finding typically associated with upper femoral epiphysiolysis (Duthie and Ferguson 1973). A high proportion (16 hips) showed evidence of tilt deformity of the femoral head on anteroposterior radiograph (Figure 3) with femoral head ratios equal to or greater than 1.35 (Murray and Duncan 1971). The distribution of the femoral head ratios is shown in Figure 2.

\section{DISCUSSION}

Of special interest in these cases was the limitation of hip joint movement, particularly internal rotation. This limitation was not gross but was significant. Most other hip joint movements in these patients were within normal limits. Close examination and comparison of the $X$-rays revealed, in one case early degenerative joint disease. In ten cases tilt deformaties of one or both femoral heads were noted on A-P radiography consistent with mild traumatic disturbances of the proximal femoral epiphysis in adolescence with the typical flattening of the junction between the head and neck of the femur on the superior aspect.

The incidence of tilt deformity in this group of patients is 83.3 per cent $(66.7$ per cent of hips examined) in contrast to the incidence the athletic population generally of $\mathbf{2 5 . 5}$ per cent and in a control group of 10 examples per 100 hips examined (Murray and Duncan). This incidence is significantly higher than could arise by chance, even in an athletic population.

Re-examination of material published elsewhere indicates that while tilt deformities of the femoral heads are demonstrable in the majority of those cases illustrated with roentgenographs that include the hip joints (e.g Adams and Chandler 1953, Schwarzweller 1964), there is yet specific reference in only two of the papers cited to limitation of hip joint movement (Howse 1964, Bose 1972) and none to the deformity of the femoral heads; Cochrane (1971) however, does refer to pain in hip movement. Unfortunately Harris and Murray have not related any findings of tilt deformity of the femoral 

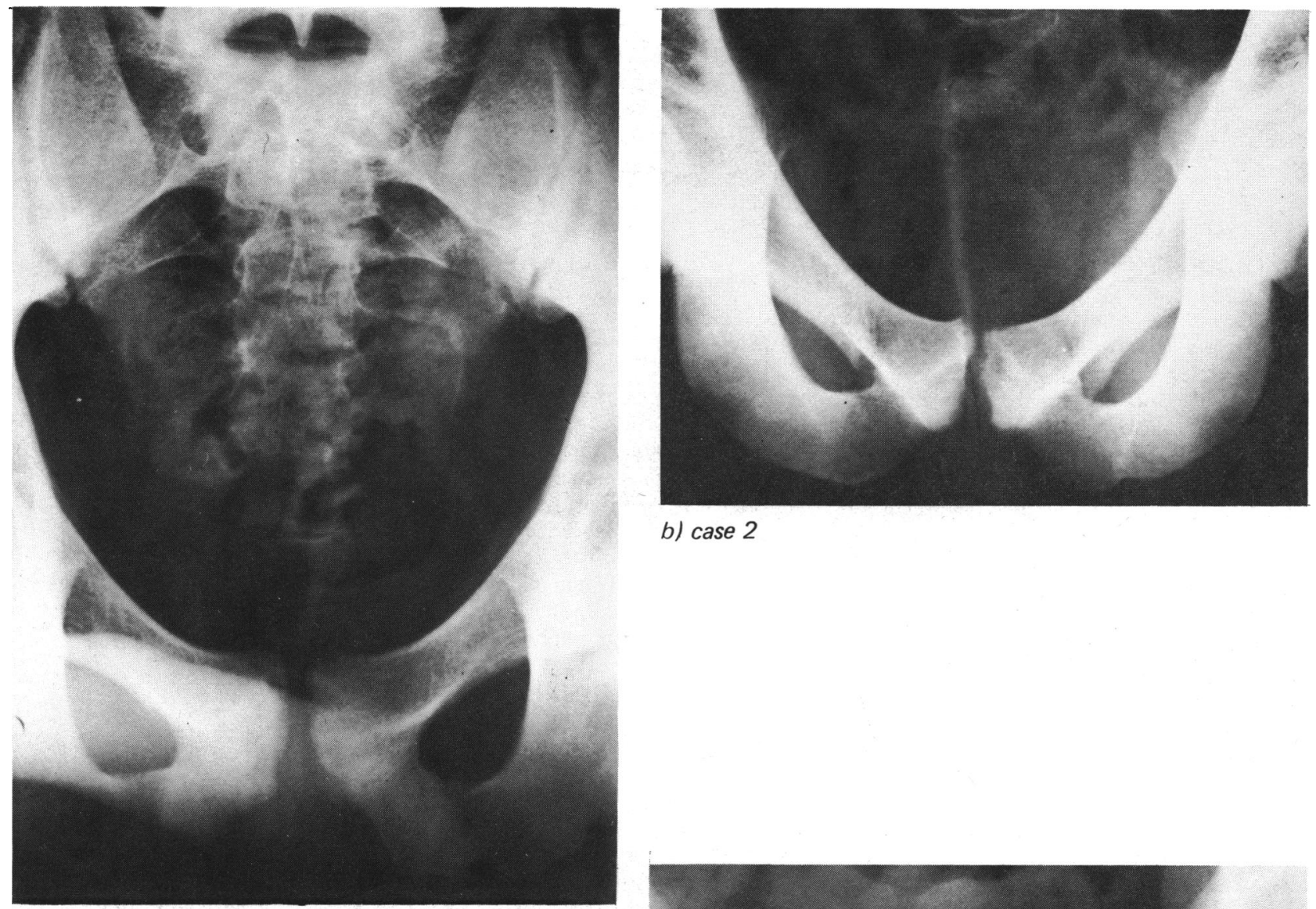

b) case 2

a) case 1

c) case 3

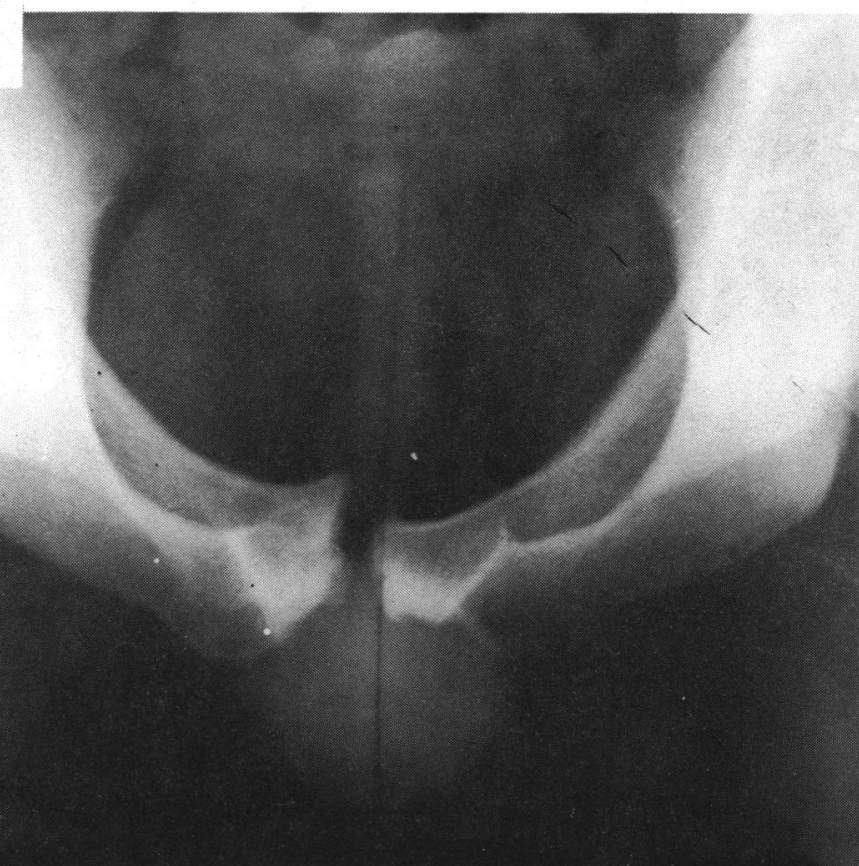

Figure 1 Radiological appearances in traumatic osteitis pubis, 
TABLE I

Details of Cases

N.B. Internal rotation is measured in flexion to nearest $5^{\circ}$

\begin{tabular}{|c|c|c|c|c|c|c|c|c|c|}
\hline \multirow[t]{2}{*}{$\begin{array}{l}\text { Case } \\
\text { No. }\end{array}$} & \multirow[t]{2}{*}{ Age } & \multirow[t]{2}{*}{ Sport } & \multirow[t]{2}{*}{$\begin{array}{l}\text { Length of } \\
\text { Disability }\end{array}$} & \multicolumn{2}{|c|}{$\begin{array}{l}\text { Internal } \\
\text { Rotation }\end{array}$} & \multicolumn{2}{|c|}{$\begin{array}{l}\text { Femoral } \\
\text { Head Ratio }\end{array}$} & \multicolumn{2}{|c|}{$\begin{array}{l}\text { Tilt } \\
\text { Deformity }\end{array}$} \\
\hline & & & & $\mathbf{R}$ & $\mathbf{L}$ & $\mathbf{R}$ & $\mathbf{L}$ & $\mathbf{R}$ & $\mathbf{L}$ \\
\hline 1 & 23 & Football & 2 months & 30 & 20 & 1.46 & 1.7 & + & + \\
\hline 2 & 19 & $\begin{array}{l}\text { Professional } \\
\text { Football }\end{array}$ & 3 months & 25 & 35 & 1.87 & 1.08 & + & - \\
\hline 3 & 22 & Rugby & 3 months & 30 & 40 & 1.27 & 1.11 & - & - \\
\hline 4 & 16 & Football & 7 months & 30 & 45 & 1.36 & 1.2 & + & - \\
\hline 5 & 23 & $\begin{array}{l}\text { International } \\
\text { Rugby }\end{array}$ & 6 months & 35 & 45 & 1.08 & 1.16 & - & - \\
\hline 6 & 29 & Karate & 9 months & 40 & 30 & 1.66 & 182 & + & + \\
\hline 7 & 27 & $\begin{array}{l}\text { Professional } \\
\text { Football }\end{array}$ & 7 months & 30 & 40 & 1.51 & 1.56 & + & + \\
\hline 8 & 20 & Football & 4 months & 35 & 35 & 1.32 & 1.36 & - & + \\
\hline 9 & 29 & Football & 7 months & 35 & 20 & 1.44 & 1.6 & + & + \\
\hline 10 & 26 & Rugby & 8 months & 40 & 25 & 1.61 & 1.57 & + & + \\
\hline 11 & 24 & Cycling & 18 months & 30 & 30 & 1.80 & 2.5 & + & + \\
\hline 12 & 29 & $\begin{array}{l}\text { Professional } \\
\text { Football }\end{array}$ & 2 months & 45 & 30 & 0.96 & 1.41 & - & + \\
\hline
\end{tabular}

$N=12$. Al/ Male

\section{TILT DEFORMITY}

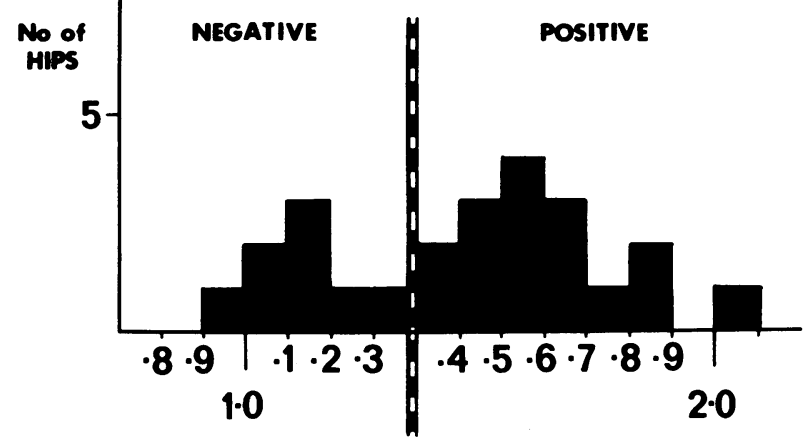

Figure 2 Distribution of Femoral head ratios in 24 hip joints in this series (after Murray and Duncan).

head to pubic lesions in their control series, although Murray and Duncan show in an illustration a patient with deformed femoral heads (and presumably limitation of hip joint movement?) with a pubic lesion.

\section{POSTULATED MECHANICAL BASIS FOR TRAUMATIC OSTEITIS PUBIS}

Patients with this condition complain that pain is felt on exercise. The game of football in particular as well as various other sporting activities (including road walking, a sport to which this condition has been attributed), all involve the participant in movements requiring free internal rotation of the hip joint, both in flexion and extension. Where such movement is restricted, stress will be applied across the hip joint to the os inominatum on the appropriate side. This stress will be specifically a shearing stress causing inward or outward movement (antero-posterior) of one half of the pelvis in relation to the other in extension, (Figure 4a) or upward or downward movement (proximo-distal) in flexion (Figure 4b). Such forces are perhaps less liable to be applied in other instances of pathological diminution of hip joint movement (for example in degenerative joint disease) where soft-tissue tension rather than abnormal joint shape is the restricting factor, or there is loss of range of other movements as well.

It seems not unreasonable, therefore, to suggest that the development of osteitis pubis may be related to damage caused at the symphysis by the imposition of shearing stress, which would also explain the incidence of sacro-iliac disturbances in this condition mentioned by Harris and Murray. If this is indeed the situation, then it follows that the management of patients com- 


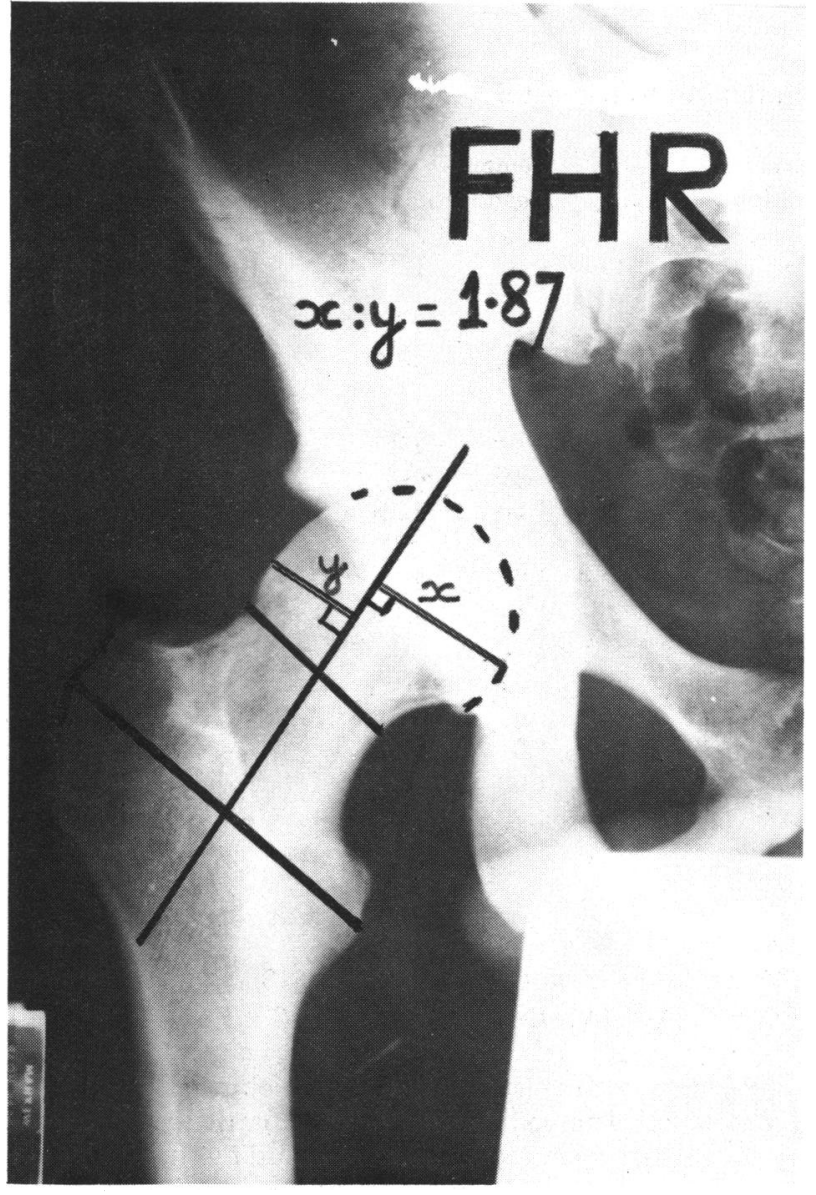

Figure 3 Estimation of Femoral Head Ratio on Anteroposterior Radiograph (Case 2).

plaining of inguinocrural pain will often require not merely attention to the local lesion but also to hip mobility; patients found to have restricted mobility will need rehabilitation programmes devised to restore mobility to normal. Where such restoration of mobility proves to be impossible, the patient may have to be guided to some other form of sporting activity. In such
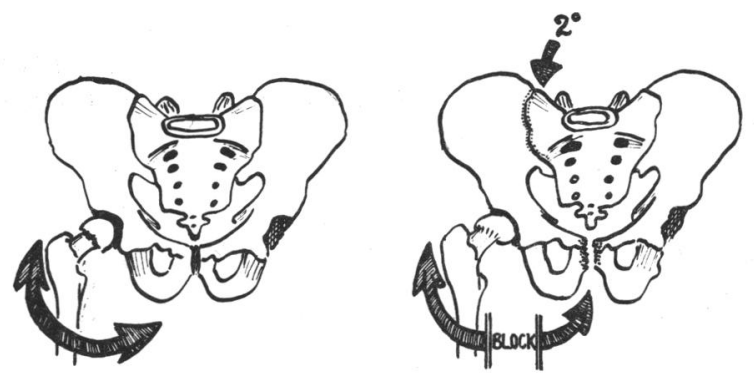

A
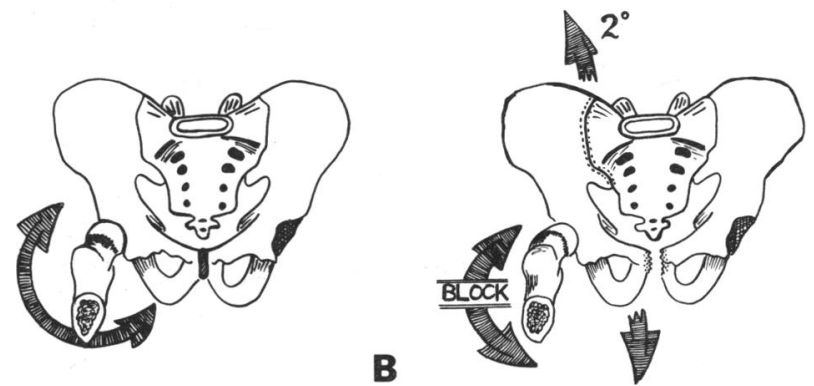

Figure 4 Postulated Mechanism of Shearing Stress on Symphysis with limitation of rotation (a) in extension and (b) in flexion.

cases detection of demonstrable hip pathology would facilitate an explanation to the patient of the reason why he has to abandon his previous sport.

\section{ACKNOWLEDGEMENT}

I am most grateful to Dr. A. Barr, Regional Information Scientist, Oxford Regional Health Authority, for his statistical advice in the preparation of this paper.

It is also a pleasure to acknowledge with gratitude the advice of Dr. R. O. Murray in the interpretation of the radiographs.

\section{REFERENCES}

Adams, R. J. and Chandler, F. A. 1953. Osteitis Pubis of Traumatic Etiology. J.Bone Joint Surg., 35A: 685.

Bose, E. 1970. Gutachterliche Problematik bei dem Krankheitsbild der Ostitis Pubis. Der Radiologue, 10: 248.

Carnevale, V. 1954. La denominada 'Inguinocruralgia Traumatic de los Jugadores de Futbol'. Prensa Med.Argent., 41: 355.

Cochrane, G. M. 1971. Osteitis Pubis in Athletes. Brit.J.Sports Med., 5: 233. 
Duthie, R. B. and Ferguson, A. B. 1973. Mercer's Orthopaedic Surgery. Edward Arnold, London.

Harris, N. H. and Murray, R. O. 1974. Lesions of the Symphysis in Athletes. Brit.Med.J., 4: 211.

Howse, A. J. G. 1964. Osteitis Pubis in an Olympic Road Walker. Proc.R.Soc.Med., 57: 88.

Lang, A. 1972. Osteitis Pubis. Rev. Bras. Med., 26: 639.

Losada, A. and Saldias, E. 1968. Osteopatia dinamica del pubis. Revista.Medica, 96: 110.

Murray, R. O. and Duncan, C. 1971. Athletic activity in Adolescence as an Etiological Factor in Degenerative Hip Disease. J.Bone Joint Surg., 53B: 406.

Reideberger, Von J., Luschnitz, E. and Bauchspeiss, B. 1967. The Pubic Adductor Syndrome in Footballers. Zentralblatt fur Chirurgie, 92: 2655.

Rosenklint, A. and Bach Anderson, R. 1969. Tenosteochondrosis of the Pubis. Acta Rheum.Scand., 15: 262.

Russe, O. A. and Gerhardt, J. J. 1975. International SFTR Method of Measuring and Recording Joint Motion. Hans Huber, Bern.

Schneider, P. G. 1963. Das Grazilissyndrom. Z.Orthop., 98: 43.

Schwarzweller, F. 1964. Kasnistischer Beitrag Zum Krankheitsbild der sog. 'Ostitis Necroticans Pubis'. Münch.Med.Wschr., 2055.

Williams, J. G. P. 1976. in Sports Medicine 2nd Edn., Williams, J. G. P. and Sperryn, P. N. Eds., Edward Arnold, London. 